\title{
Application Design of Electronic ID Card
}

\author{
Apri Susanto, Phong Thanh Nguyen, K.C. Ramya, K. Shankar, Satria Abadi, Wahidah Hashim, \\ Andino Maseleno
}

\begin{abstract}
The development and advancement of information technology has a lot of benefits for the institutions that implement it included in the field of government bureaucracy. The application of e-government to the government bureaucracy certainly can make the performance of government better. The application of information technology in the field of government such as in matters of making Identity Card, Bahasa: Kartu Tanda Penduduk (KTP), is certainly able to provide a change in the bureaucratic system of making Identity Card. As in the Pringsewu District that is originally used a manual system in making Identity Card that is certainly very inefficient and requires a long time so that many residents are reluctant to take care of making Identity Card. Surely this is very unfortunate remembering the importance of Identity Card. Because of this reason, the author tries to examine the design of an application for making an Electronic Identity Card with the aim to ease the public or to take care of making Citizenship Cards online, in addition to that, this application will also help the performance of the Population and Civil Registry Office so that the service provided to the public is more optimal. It is expected that people will no longer to be reluctant to take care of making a Electronic Identity Card with the application.
\end{abstract}

Keywords : E-KTP, Pringsewu, Society, E-Government.

\section{INTRODUCTION}

\section{A. Bakcground}

The rapid development and advancement of information technology along with various potential users can open various opportunities that facilitate human performance [1]. The use of information technology has penetrated many fields, from business, education and government [2]. Surely, this is expected to be able to support a variety of public activities such as improved, clean and transparent public services and able to answer the wishes of the public who want public services that meet the interests of the wider community from various layers [3]. Therefore, it is necessary to design and develop a more flexible system and work process and has functions to facilitate various forms of

Revised Manuscript Received on July 22, 2019.

* Correspondence Author

Apri Susanto, Department of Information Systems, STMIK Pringsewu, Lampung, Indonesia.

Phong Thanh Nguyen*, Department of Project Management, Ho Chi Minh City Open University, Vietnam. E-mail: phong.nt@ou.edu.vn

K.C. Ramya, Associate Professor/EEE, Sri Krishna College of Engineering and Technology, Coimbatore, India. E-mail: ramyakc@skcet.ac.in

K. Shankar, Department of Computer Applications, Alagappa University, India. E-mail: shankarcrypto@gmail.com

Satria Abadi, Department of Information Systems, STMIK Pringsewu, Lampung, Indonesia.

Wahidah Hashim, Institute of Informatics and Computing Energy, Universiti Tenaga Nasional, Malaysia.

Andino Maseleno, Institute of Informatics and Computing Energy, Universiti Tenaga Nasional, Malaysia interaction from various groups and fields such as business education and government bureaucracy [4]. The implementation of E-Government in this process is very important to support the formation of a structured and computerized system [5]. The E-Government implementation system is also applied in Pringsewu District, so Pringsewu Regency Government's work system has become more programmed and organized in the data processing especially for population data [6]. This is because in the field of population administration has not shown the accommodative and bureaucratic nature but it shows the complex and prolonged bureaucracy [7]. This is because the population administration sector in Pringsewu Regency has not shown accommodative nature to the needs and demands desired by the community [8]. For this reason, Author intended to write about the population system in making Identity Cards using applications [9]. It is expected that the author write this topic, it can help residents of Pringsewu District with a sample of pringkumpul village in making the Identity Card and can facilitate officers in making and storing the population data [10].

\section{B. Problem Formulation}

Based on the background that described from the discussion of this research, then some of the formulation of the problems to be studied are:

a. How is the design of application for making Electronic Identity Card in Pringsewu District?

b. What are the steps in making Electronic Identity Card (E-KTP) in Pringsewu District?

c. What are the benefits / advantages of implementing the application for making an electronic identity card (E-KTP) in Pringsewu District?

\section{Problem Limitation}

Based on the description explained, the authors limit the problems in this study namely:

a. The application designed is only limited in making E-KTP

b. The design of the application for making E-KTP is only focused on information services

c. Analysis and design of the application for making E-KTP does not discuss the advanced computer security systems and networks contained in the E-KTP application.

d. The design of the application for making E-KTP is aimed at Pringsewu sub-district with a sample of pring kumpul village. 


\section{Application Design of Electronic ID Card}

e. This application only ends at the printing process stage because the physical form of the finished E-KTP can be taken in the village because the user must submit a photo and perform the biometric process.

\section{Objectives}

The objectives of this research were :

a. To know how to make an Electronic Identity Card (E-KTP) in Pringsewu District [11].

b. To know the steps in making Electronic Identity Card (E-KTP) in Pringsewu District [12].

c. To Know the advantages / benefits of Electronic Identity Card (E-KTP) in Pringsewu Regency [13].

\section{E. Benefit}

The expected benefits were :

a. To Improve better relations between the government and the general public [14]

b. Can help improve better services to the community [15].

c. To imporve author's insight about how the process of making E-KTP in Pringsewu District [16].

d. Empowering the community through more efficient information [17].

\section{F. Research Methodology}

Time and place of the study

To obtain the data needed to support the implementation of this study [18], it was used several data collection techniques namely:

a. Observation. A data collection technique by direct observation of objects in the field [19].

b. Interview. Interview was conducted in this study with related parties in making KTP in the Pringsewu sub-district [20]

\section{LITERATURE REVIEW}

\section{A. Definition of E-Government}

E-government is an electronic-based management information system to assist the government in providing information [21], providing public services and allowing online transactions to other entities / companies or with the people with good quality [22]. E- Government is a process in government system by utilizing ICT (information, communication and technology) [23] as a tool to facilitate the communication process and transactions for citizens [24], business organizations and between government agencies and their staff [25]. So that efficiency, effectiveness, transparency and accountability of government can be achieved to the community [26].

E-Government (E-Gov) is the use of information technology that can improve relations between government and other implementing the application in making an

parties that involves the automation [27] and computerization of paper based procedures that will encourage new ways of leadership [28], new ways of discussing and defining strategies, new ways of business transactions [29], new ways of listening to citizens and communities, and new ways to organize and convey information [30].

From some of the statements above, it can be concluded that E-Government is a governmental system process using Information [31], Communication and Technology or ICT that can improve relations between the government and many parties that will encourage new ways of leadership and matters related to leadership [32].

\section{B. Definition of Application}

Application is computer programs created to work on programs [33]. Application Interface is a collection of software that allows a programmer to enter a system and use the services provided on a network [34]. Application is a computer program created to work on or solve specific problems [35].

From some of the statements above, it can be concluded that application is a computer program specifically designed to help human tasks based on the needs [36].

\section{Definition of Electronic Identity Card (E-KTP)}

In Law Number 23 of 2006, Electronic Identity Card, hereinafter referred to as e-KTP is the official identity of the resident as proof of self issued by Implementing Agency that is valid in all regions of the the Republic of Indonesia.

According to Permendagri Number 9 of 2011 concerning the guidelines for issuance of Identity Card based on a national Population Identification Number in article 1 paragraph (9), it explains about NIK-based KTP nationally hereinafter referred to as Electronic KTP is Identity Card that has specifications and formats for National KTP with a special security system that applies as official identity issued by the Regency / City Population and Civil Registry Office [37].

The E-KTP is an electronic generated Identity Card that has a computerized function and has the specification and National KTP Format that is protected with a special security system as the official identity of the population issued by the Regency / City Population and Civil Registry Office [39].

From some of the statements above, it can be concluded that E-KTP is a computerized identification card [40] that has a special computerized specifications and standards as well as a special official security system issued by the Department of Population and Civil Registration [41].

\section{Location of Pringsewu District}

Pringsewu is one of the Regencies in Lampung Province, Indonesia. This regency was approved as a regency in the DPR Plenary Meeting on 29 October 2008, as a division of Tanggamus Regency. The Regency is located 37 kilometers of west of Bandar Lampung, the provincial capital. 

because of its good development [42][43], both in terms of regional income, economic level and population education [44][45]. The main livelihoods in Pringsewu are farming and trading. The location is very strategic [46], it is unfortunate if it is not utilized by the local government to develop Pringsewu.

\section{DESIGN}

Figure 1 shows Interface Design Home Page.

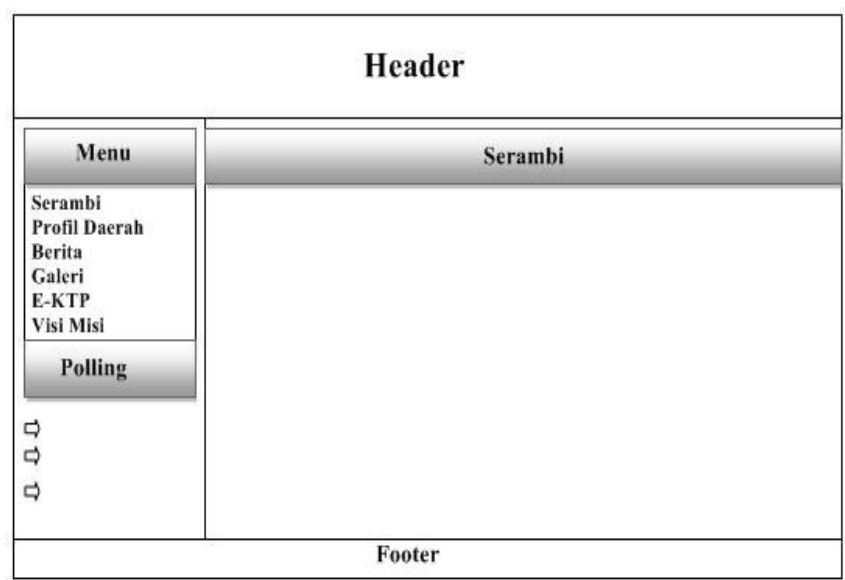

Figure 1. Interface Design Home Page

Figure 2 shows interface login page design.

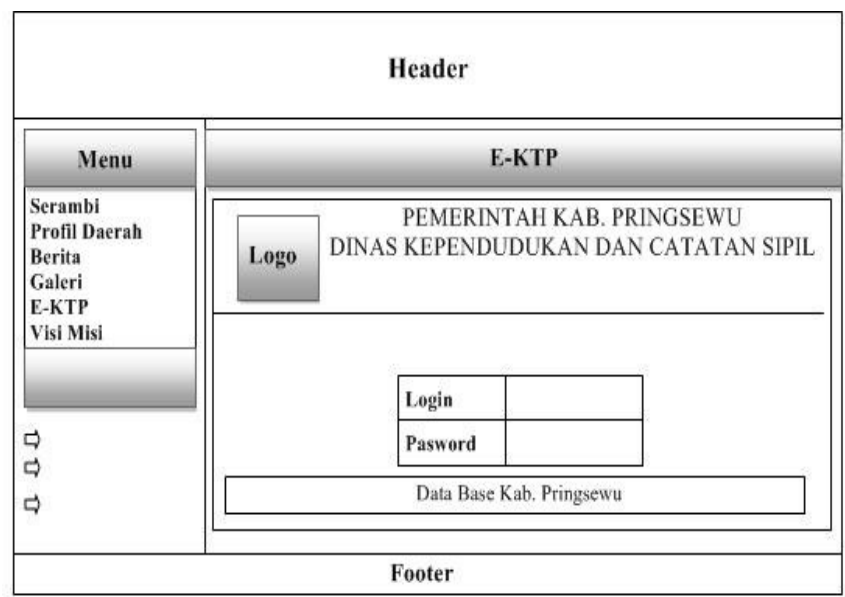

Figure 2. Interface Login Page Design

Figure 3 shows interface design of population data menu.

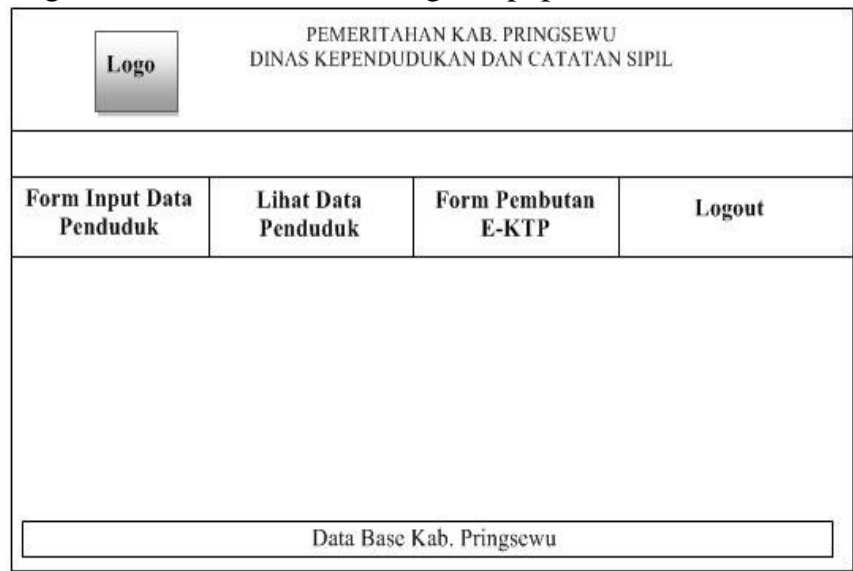

Figure 3. Interface Design of Population Data Menu
Pringsewu is currently approved to be a separate district

Figure 4 shows interface design of population data input.

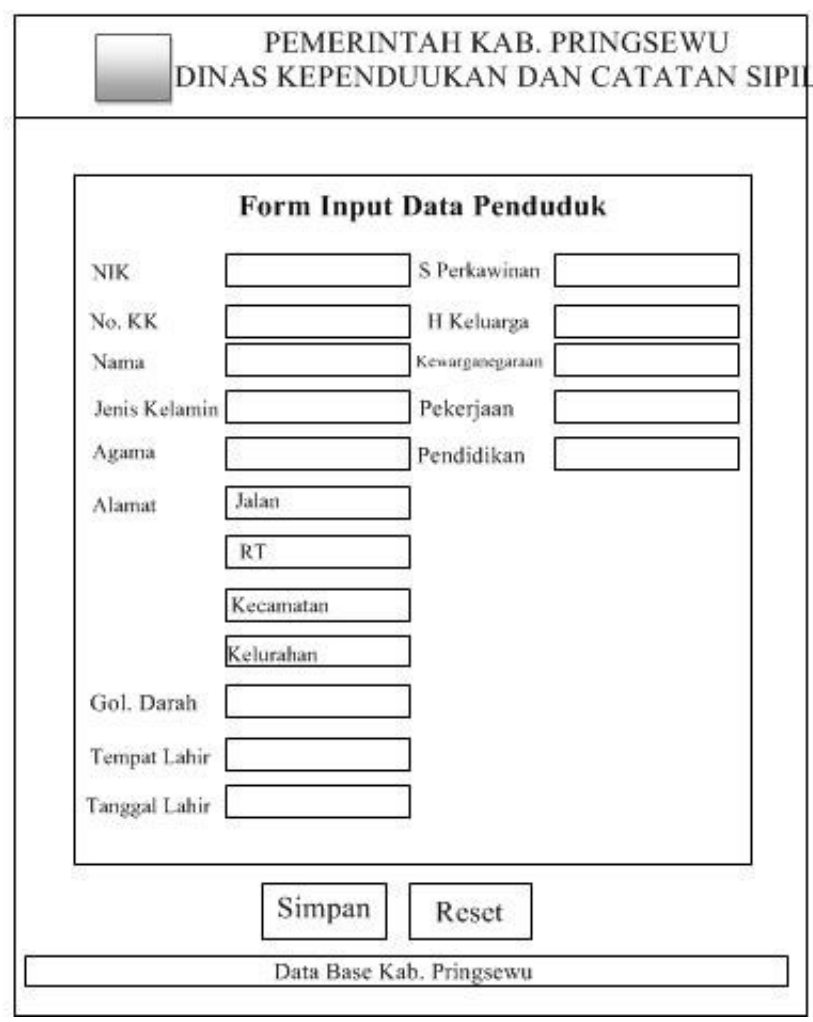

Figure 4. Interface Design of Population Data Input

Figure 5 shows interface design in creating E-KTP.

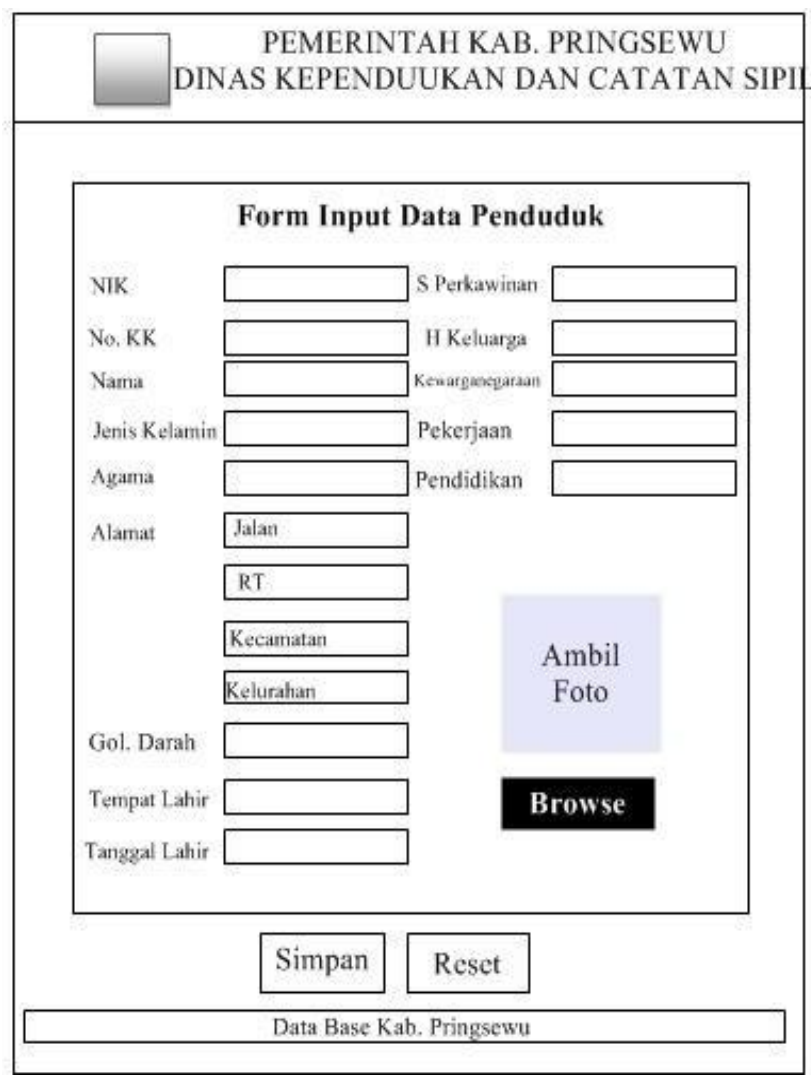

Figure 5. Interface Design in Creating E-KTP 


\section{Application Design of Electronic ID Card}

Figure 6 shows interface design in printed E-KTP

\begin{tabular}{|c|c|c|}
\hline & $\begin{array}{c}\text { PROVINSI LAMPUNG } \\
\text { KABUPATEN PRINGSEWU }\end{array}$ & \\
\hline NIK & & \\
\hline Nama & & \\
\hline Tempat/Tgl Lahir & & i \\
\hline Jenis Kelamin & & i \\
\hline Alamat & : & 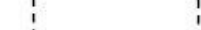 \\
\hline RT & : & i \\
\hline Kel/Desa & : & 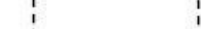 \\
\hline Kecamatan & : & 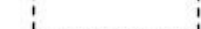 \\
\hline Agama & : & Pringsewu \\
\hline Status Perkawinan & & \\
\hline Pekerjaan & : & \\
\hline Kewarganegaraan & : & \\
\hline Berlaku Hingga & & Tanda Tangan \\
\hline & & Pemegang E-KTP \\
\hline
\end{tabular}

Figure 6. Interface Design in Printed E-KTP

Figure 7 shows interface design of logout page

\begin{tabular}{|c|c|}
\hline Logo & PEMERINTAH KAB. PRINGSEWU \\
\hline DINAS KEPENDUDUKAN DAN CATATAN SIPIL \\
Logout \\
Login \\
Anda sudah keluar klik disini untuk masuk
\end{tabular}

Figure 7. Interface Design of Logout Page

\section{CONCLUSION}

Based on the results of research on the design of a web-based E-KTP creation application in Pringsewu District with a sample of Pringkumpul Village, it can be concluded as follows:

a. The E-Government application facilitates the residents to make E-KTP easily, cheaply and quickly. This application also helps improve government performance to be more effective and efficient so that the services provided to the community become better.

b. By adopting E-Government, the process of making E-KTP will experience changes by online.

As a suggestion to support the continuity of the proposed system to meets the expected needs. In order to get better and perfect results designed in this study, it is necessary to do a trial to complete this system and develop this system better.

\section{REFERENCES}

1. Ambika, P., Ayshwarya, B, Livshits, Y.A., Nguyen, P.T., Hashim, W., Shankar, K., Maseleno, A., Self-education as a condition of professional and personal development of a future specialist, Religación. Revista de Ciencias Sociales y Humanidades, Vol. 4, No. 16, 2019. pp. 499-205. http://revista.religacion.com/index.php/about/article/view/292/251

2. Suhartono, Nguyen, P.T., K. Shankar, K., Hashim, W., Maseleno, A., Brain Tumor Segmentation and Classification using KNN Algorithm,
International Journal of Engineering and Advanced Technology, Vol. 8, Issue $\quad 6 \mathrm{~S}, \quad 2019 . \quad$ pp.706-711. https://www.ijeat.org/wp-content/uploads/papers/v8i6S/F11370886S19. pdf

3. Muruganantham A., Nguyen, P.T., Lydia, E.L., Shankar, K., Hashim, W., Andino Maseleno, Big Data Analytics and Intelligence: A Perspective for Health Care, International Journal of Engineering and Advanced Technology, Vol. 8, Issue 6S, 2019. pp.861-864. https://www.ijeat.org/wp-content/uploads/papers/v8i6S/F11620886S19. pdf

4. Asih, E.S., Kasmi, Nguyen, P.T., Lydia, E.L., Shankar, K., Hashim, W., Andino Maseleno, A., Mobile E-Commerce Website for Technology-Based Buying Selling Services, International Journal of Engineering and Advanced Technology, Vol. 8, Issue 6S, 2019. pp.884-888

https://www.ijeat.org/wp-content/uploads/papers/v8i6S/F11670886S19. pdf

5. Kumar, R., Ayshwarya, B., Konovalova, E.Y., Nguyen, P.T., Hashim, W., Shankar, K., Maseleno, A., Approaches and technologies for the formation of future specialists' motivation, Religación. Revista de Ciencias Sociales y Humanidades, Vol. 4, No. 16, 2019. pp. 492-498. http://revista.religacion.com/index.php/about/article/view/291/250

6. Rusliyadi, M., Kumalasari, R.T., Nguyen, P.T., Hashim, W., Maseleno, A., Potential Jatropha Curcas (Jatropha Curcas L.) Germplasm by Exploration In Gorontalo Province Indonesia, International Journal of Recent Technology and Engineering (IJRTE), Vol. 8, Issue 2S3, 2019 pp.1617-1624.

https://www.ijrte.org/wp-content/uploads/papers/v8i2S3/B12950782S3 19.pdf

7. Ambika P., Ayshwarya, B., Nguyen, P.T., Hashim, W., Rinjani, F., Muslihudin, M., Shankar, K., Denisova, O.P., Maseleno, A., The Best of Village Head Performance: Simple Additive Weighting Method, International Journal of Recent Technology and Engineering (IJRTE), Vol. 8, Issue 2S3, 2019. pp.1568-1572. https://www.ijrte.org/wp-content/uploads/papers/v8i2S3/B12860782S3 19.pdf

8. Sivaram, M., Ayshwarya, B., Hashim, W., Nguyen, P.T., Shankar, K., Prabowo, E., Abadi, S., Huda, M., Ochepovsky, A.V., Maseleno, A. School Now, Pay Later, Revista San Gregorio, No. 32, Special Issue August 2019. pp. 196-203. http://revista.sangregorio.edu.ec/index.php/REVISTASANGREGORIO /article/view/1075/TRR6

9. Sivaram, M., Ayshwarya, B., Pribadi, M.R., Nguyen, P.T., Shankar, K Mohammed, A.S., Abadi, S., Huda, M., Putra, D.P., Hashim, W., Maseleno, A., Porkodi, V., Manikandan, V., Ochepovsky, A.V., Saving Private Money, Revista San Gregorio, No. 32, Special Issue August $2019 . \quad$ pp. 204-211. http://revista.sangregorio.edu.ec/index.php/REVISTASANGREGORIO /article/view/1077/trr7

10. Maseleno, A., Ayshwary, B., Ivanova, T.N., Hashim, W., Nguyen, P.T Shankar, K., Kristiawan, M., Huda, M., General theoretical and philosophical aspects of modern education, Revista San Gregorio, No. 32 Special Issue August 2019. pp. 212-217. http://revista.sangregorio.edu.ec/index.php/REVISTASANGREGORIO /article/view/1079/trr8

11. Ayshwarya, B., Nguyen, P.T., Bazar, F.A., Aminudin, N., Shankar, K., Hashim, W., Larisa N. Gorina, Maseleno, A., Aqua Bill Store Mineral Water Sales Application Program, International Journal of Recen Technology and Engineering (IJRTE), Vol. 8, Issue 2S3, 2019. pp.1495-1499.

https://www.ijrte.org/wp-content/uploads/papers/v8i2S3/B12740782S3 19.pdf

12. Mukhlis, H., Ayshwarya, B., Nguyen, P.T., Hashim, W., Hardono, Maesaroh, S., Sagita, Y.D., Surmiasih, Sanjaya, R., Oktafianto, Shankar, K., Denisova, O.P., Maseleno, A., Boarding House Selection using SAW Method, International Journal of Recent Technology and Engineering (IJRTE), Vol. 8, Issue 2S3, 2019. pp.1500-1506 https://www.ijrte.org/wp-content/uploads/papers/v8i2S3/B12750782S3 19.pdf

13. Ayshwarya, B., Yansyah, A., Nguyen, P.T., Shankar, K., Hashim, W., Satria Abadi, S., Odarich, I.N., Maseleno, A., Design Analysis of Web-Based Employee Information System in Office of Technical Implementation Unit of Education Department, International Journal of Recent Technology and Engineering (IJRTE), Vol. 8, Issue 2S3, 2019. pp.1507-1512. https://www.ijrte.org/wp-content/uploads/papers/v8i2S3/B12760782S3 19.pdf

Published By:

Blue Eyes Intelligence Engineering \& Sciences Publication 
14. Ayshwarya, B., Nguyen, P.T., Alismi, Satria Abadi, Shankar, K., Hashim, W., Aleksandr A. Korostelev, Maseleno, A., Design Analysis of Web-Based Furniture Marketing Information System, International Journal of Recent Technology and Engineering (IJRTE), Vol. 8, Issue 2S3, $2019 . \quad$ pp.1513-1519. https://www.ijrte.org/wp-content/uploads/papers/v8i2S3/B12770782S3 19.pdf

15. Ayshwarya, B., Firdiansah, F.A., Firmansyah Y. Alfian, F.Y., Nguyen, P.T., Hashim, W., Shankar, K.,Abadi, S., Peteraitis, S.K., Maseleno, A., The Best Land Selection using SAW, International Journal of Recent Technology and Engineering (IJRTE), Vol. 8, Issue 2S3, 2019. pp.1520-1525.

https://www.ijrte.org/wp-content/uploads/papers/v8i2S3/B12780782S3 19.pdf

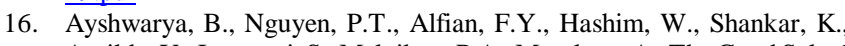
Aprilda, Y., Ipnuwati, S., Melnikov, P.A., Maseleno, A., The Good Salted egg using AHP, International Journal of Recent Technology and Engineering (IJRTE), Vol. 8, Issue 2S3, 2019. pp.1526-1532. https://www.ijrte.org/wp-content/uploads/papers/v8i2S3/B12790782S3 19.pdf

17. Kumar R., B. Ayshwarya, Muhamad Muslihudin, Nguyen, P.T., Firmansyah Y. Alfian, Hashim, W., Shankar, K., Siti Hafizah, Siti Mukodimah, Irina N. Odarich, Maseleno, A., Into the Furniture Woods: Analytical Hierarchy Process Method, International Journal of Recent Technology and Engineering (IJRTE), Vol. 8, Issue 2S3, 2019. pp.1562-1567.

https://www.ijrte.org/wp-content/uploads/papers/v8i2S3/B12850782S3 19.pdf

18. Chienwattanasook, K., Wattanapongphasuk, W., Prianto, A., \& Jermsittiparsert, K. 2019. "Corporate Entrepreneurship and Business Performance of Logistic Companies in Indonesia.” Industrial Engineering \& Management Systems 18 (3): 538-547.

19. Dawabsheh, M., Hussein, A., \& Jermsittiparsert, K. 2019. "The Triangular Relationship between TQM, Organizational Excellence and Organizational Performance: A Case of Arab American University Palestine." Management Science Letters 9 (6): 921-932.

20. Jermsittiparsert, K., Siam, M., Issa, M., Ahmed, U., \& Pahi, M. 2019. "Do Consumers Expect Companies to $\mathrm{Be}$ Socially Responsible? The Impact of Corporate Social Responsibility on Buying Behavior." Uncertain Supply Chain Management 7 (4): 741-752.

21. Syazali, M., Putra, F., Rinaldi, A., Utami, L., Widayanti, Umam, R., \& Jermsittiparsert, K. 2019. "Partial Correlation Analysis Using Multiple Linear Regression: Impact on Business Environment of Digital Marketing Interest in the Era of Industrial Revolution 4.0." Management Science Letters 9 (11): 1875-1886.

22. Sae-Lim, P. \& Jermsittiparsert, K. 2019. "Is the Fourth Industrial Revolution a Panacea? Risks toward the Fourth Industrial Revolution: Evidence in the Thai Economy." International Journal of Innovation, Creativity and Change 5 (2): 732-752.

23. Chatchawanchanchanakij, P., Arpornpisal, C., \& Jermsittiparsert, K. 2019. "The Role of Corporate Governance in Creating a Capable Supply Chain: A Case of Indonesian Tin Industry." International Journal of Supply Chain Management 8 (3): 854-864.

24. Hartinah, S., Suharso, P., Umam, R., Syazali, M., Lestari, B., Roslina, R., \& Jermsittiparsert, K. 2020. "Teacher's Performance Management: The Role of Principal's Leadership, Work Environment and Motivation in Tegal City, Indonesia." Management Science Letters 10 (1): 235-246.

25. Somjai, S. \& Jermsittiparsert, K. 2019. "The Trade-off between Cost and Environmental Performance in the Presence of Sustainable Supply Chain." International Journal of Supply Chain Management 8 (4): 237-247.

26. Jermsittiparsert, K. \& Sawasdee, A. 2012. "Formal Education for Non-Thai or Undocumented Person in Thailand amidst the Challenge of Nationalism and Transnationalism: A Case Study of Wat Sirimongkhol School, Samut Sakhon Province." Kasetsart Journal - Social Sciences 33 (2): 203-213. 